23 (6) : 407-419, 1973

\title{
神経の相対不応期に現れる活動電位の 大いさについて
}

\author{
半場道子 \\ 群馬大学医学部第一生理学教室 (主任松本政雄教授)
}

\section{I 緒言}

神経ないし神経線維が興奮した後, 刺激作用の強さ に関係なく刺激に対して全く反応しない期間があり， それに続いて正常の場合より強い刺激作用を加えれば 正常の場合より小さい興奮が起る期間 3) 12) 16) 17) 20) が あって, この期間を経て正常の状態て戻る. 前者を絶 対不応期, 後者を相対不応期と呼んでいる.

絶対不応期, 相対不応期の成因については松本, 北 村および著者等 ${ }^{10)}$ の研究がある. 相対不応期に関連し て, その期間に現れる興奮（活動電位）は正常の場合 のものより小であることが知られ，12)16)18)21）この現象 が相対不応期の特徵であり，相対不応期と不可分の関 係にあるものの如く記載されている場合が多い. ${ }^{516)}$ 果 してそうであるか否か, 事実は多くの文献に記載され ているが，よって起る原因につんての研究は殆んどな 々.

著者等は, 神経線維の等価回路を電気的素子を以っ て構成した電気的神経模型（ENM）を創案し，乙の 模型におらては神経線維におらて現れる既知の電気的 現象はことでとく相似の状態において発現するととを 報告 $^{6)}{ }^{8)}$ した。 また，乙れを用いて適応，不応期等の 成因についても研究したが, 本論文はてれらの研究と 同様な立場において，ENM 老用いて標題の問題の解 明を企てた実験の報告である.

\section{II 実験 方 法}

実験材料，および刺激電流等を適用し活動電位 (AP) その他の電気的変動を誘導する方法は, 松本, 北村お よび著者の研究 ${ }^{9)}$ において使用したものと殆んど同様 であるので，ととではそれらの要点のみを述べるとと にする.

\section{A. 実験材料}

\section{1. 坐骨神経}

実験材料としてはカエルの坐骨神経および電気的神 経模型（E N M）の両者を用いた. 坐骨神経は食用力 エル存断頭開腹し, 常法に従って数 $c m$ の長さに切り出
しRinger 液中に浸したものを, 数時間以内に実験に 供した. 神経に電流を適用し, 活動電位などを誘導す るために図 $1(\mathrm{I})$ 一(N)に示したよらな隔絶箱を用いた。 隔絶箱は A， B，Cの3 室に区分され，AにはRinger
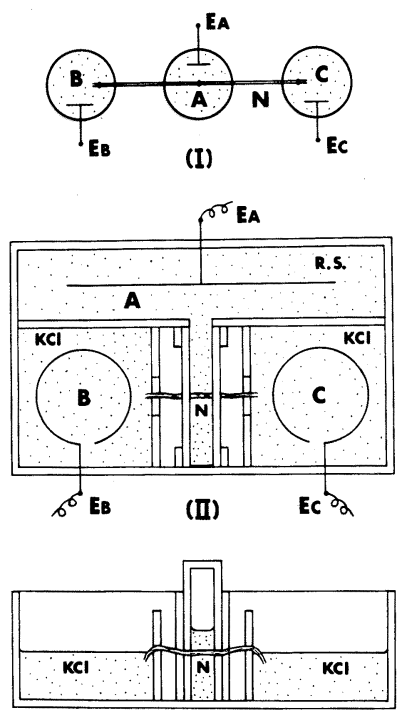

(III)

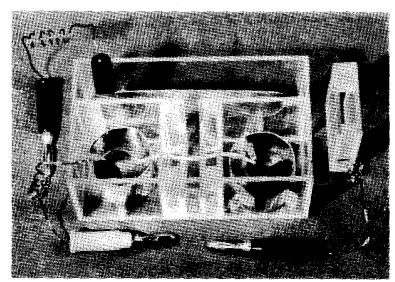

(w)

図1坐骨神経の固定に使用した隔絶箱 (I) Ranvierの絞輪につらて活動電位の誘導, 刺 激電流の適用等のために用いた方法の原理（田 崎, 1956)

(II)隔絶箱の平面図

(III)同上側面図（銀板電極なし）

(V)同上全体の写真 
(408)

液， $\mathrm{B} ， \mathrm{C}$ 亿は $\mathrm{KCl}$ 溶液を満し，それぞれの室には純 銀板の電極を浸し，それらを電気的回路（図 4) の所 定の端子に連結した。隔絶箱に固定した坐骨神経の A と B， A と Cの間の部分は空気中に露出し，乙の部分 には alcohol まをは麻醉薬を適用して興奮が伝導しな レょうにした。交た, 電極 $\mathrm{E}_{\mathrm{A}}, \mathrm{E}_{\mathrm{C}}$ から電流を適用し， $\mathrm{E}_{\mathrm{A}}, \mathrm{E}_{\mathrm{B}}$ から電気的変動を誘道した.

\section{2. 電気的神経模型 ( $E N M)$}

図 2 左は, 神経線維の等価回路として松本, 北村,

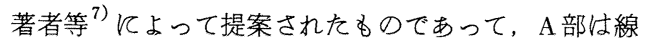

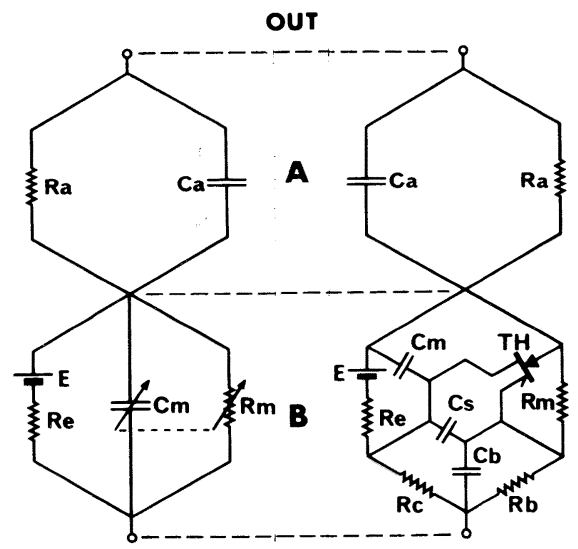

IN

図 2 神経線維の等価回路（左）と電気的神 経模型（右）
$\mathrm{A} ：$ 神経線維周囲組織の等価回路
$\mathrm{B} ：$ 興奪性膜の等価回路
OUT，IN：それぞれ神経線維の外側および内
側飞相当する部

維の外囲を構成する組織の等価回路で, 神経線維の興 舊には直接関与しないと考えられる部であるが，神経 線維とは不可分であり，乙れがこの等価回路の一つの 特徵である. B 部は, 興奮性膜の等価回路で, 神経の 興奮はこの部の㗢をによって起るものと考えられる.

さて，上述の等価回路を電気的素子を以って構成し たものが ENMであって, 図 2 右に示したものである. $\mathrm{ENM}$ の A 部は図 2 左のA 部に, B 部は同じくそのB 部に相当する回路である.

E N M 亿刺激電流を適用して興舊が現れる機序の要 点を説明すれば，次の如くである．ENMにおいて神 経線維の外側OUTに相当する部を負, 内部 IN を正と した場合の電流を外向を電流，あるいは脱分極電流と
呼ぶことにしたが，乙の方向の電流は神経線維の場合 と同様に，ある強さ以上であればE N M V興奮を起す. この場合に興奮とは, 興奮性膜の等価回路 B部の thyristor THの gateが開を，それまでOUTと INの 間に存在した電位差（静止電位）が一過性に消失する 現象を指するのであって，乙の電位変動を本論文にお らては神経等の場合に従って活動電位 (AP) と呼んだ

(図 3). ENMのAPは神経線維のAP と極めて類似 した形をしているとと, その発現には閾があり all or noneであるとと等々, およそ神経線維に現れる既知の 電気現象注，極めて類似した経過をもって E N M 亿お らても現れる。

実験とよっては，ENMのB部，すなわち興奮性膜 の等価回路を E N M 全体の代りに用いた場合もあった。

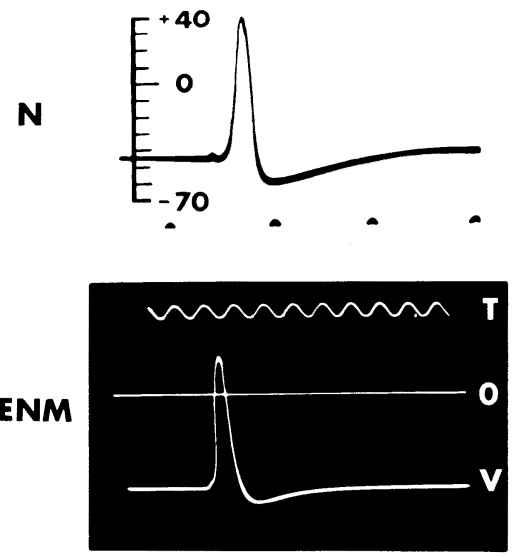

図 3 神経線維の活動電位 $(\mathrm{AP})$ と電気的 神経模型 (ENM) の活動電位

$\mathrm{N}$ : ヤリイカの巨大神経線維の AP (Hodgkin and Huxley, 1939)

ENM：ENMの活動電位, spikeの高さ約 $700 \mathrm{mV}$, ○は電位七゙口の線, 時標 $1000 \mathrm{cps}$.

B. 電気的回路

隔絶箱に固定した坐骨神経, あるいはE N M V刺激 電流などを適用し，発現した電位の変化を誘導するた めに用いた電気的回路は, 図 4 亿示すようなるのであ った. この回路は田崎 ${ }^{18)}$, 大山 ${ }^{12)}$ などが有髄神経線維 のRanvierの紋輪につんての奉験に使用した回路と原 理を同じくするものであって（図 1 (I)), 外部から適 用する刺激電流等がA P の誘導回路に現れるととが比 較的少く, 被検体内に発現した電気的変化を比較的大 をく導くことがでさる. 


\section{C. 実験操作その他}

刺激電流を標本に適用した場合に現れるA Pその他 の電気的変動は，適用した電流の期間，強さなどを示 すtrace および時標（1000 cps の交流）と共にoscil一 loscope を用いて記録した. また，実験によっては， thyristor $の$ gate と cathode 間の電位差の経過，すな わち興奮性の経過 ( EXC), condenser $\mathrm{Cm} の$ 電位 の経過, 膜電位に当る電位すなわち, 図 $4(2)$ の $\mathrm{E}_{\mathrm{A}}^{\prime}$ と $\mathrm{E}_{\mathrm{B}}$ 間の電位変動等を記録した.

\section{III 実験成 績}

実験成績を述べると先だって予めてとわっておをた レのは，坐骨神経を用いた実験では相対不応期の状態， 相対不応期中に現れる A P の高さおよび期間の小さい こと等, その他の現象についても既に知られたものが 多く，乙れらは改めて報告を要しない事実であるが， E N M における実験成績とてれらを比較するために， ENM と同様の方法で行った実験の結果を示したもの である.なお，以下の記述において，坐骨神経および
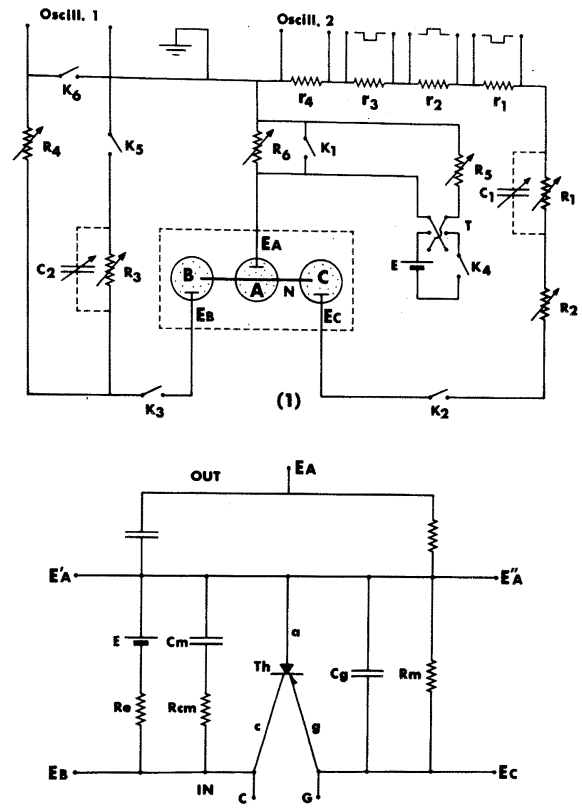

(2)

図4刺敫電流の適用, 活動電位の誘導等に 用々た電気的回路(1)とENMの回路の連結端子(2)

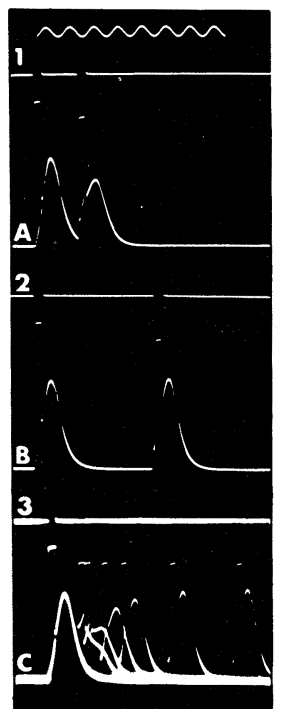

N

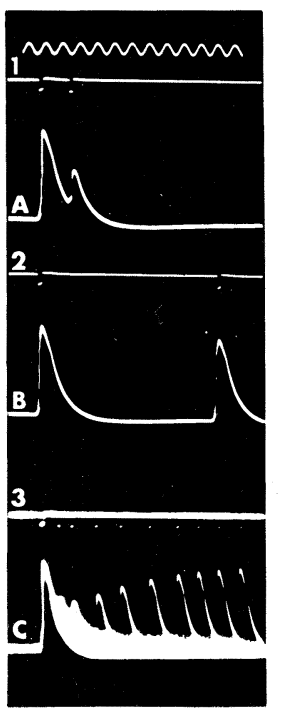

ENM

図 5 相対不応期中にやや強い刺敫電流（一定）に よって現れた AP

\section{Nの場合}

第 1 刺邀電流(a) $660 \mathrm{mV}, 0.3 \mathrm{msec}$ 第 2 刺教電流(b) $940 \mathrm{mV}, 0.3 \mathrm{msec}$ a とbの間程 1. $1.5 \mathrm{msec}$ 2. $4.5 "$
ENMの場合 $480 \mathrm{mV}, 0.2 \mathrm{msec}$ $480 \mathrm{mV}$. $0.2 \mathrm{msec}$

$1.5 \mathrm{msec}$ 10 "

C放回の記録の superimpose

NおよびENMの上はそれぞれ坐骨神経および電気 的神経模型てえられた記録，Tは時標（1000 cps）, 1,2,3 等の数字を付した trace は適用した電流の方 向（下方は脱分極電流），強さおよび期間を示し，A， $\mathrm{B}, \mathrm{C}$ 等の大交字を付したものはそれぞれ 1,2,3 等の 適用した電流に対して現れた活動電位を示す. (図 6 以下においてすすへて同じ)

E N M の実験成績が異なる場合につんてのみてれを明 記し，同様である場合は特に記述しないとととした。

A. 相対不応期中のA P の大んさ

1. A P の経過が大体終った時点から数 $\mathrm{msec} の$ 時 点までは，相対不応期であるが，乙の期間において正 常の場合の刺激閾よりやや強々一定の刺激電流老適用 すればA P が現れる. その大ささは図 5 亿示す如く， 第 1 の P の終った直後に現れる第 2 の P の高さお よび期間は最も小で，乙の時点より後て現れるA P ど高さおよび期間は大となり，遂に正常の場合のもの が現れるようになった．A P の陰性後電位と重畳して 


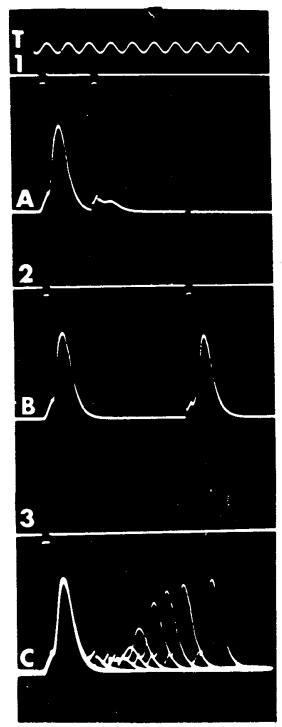

$\mathbf{N}$

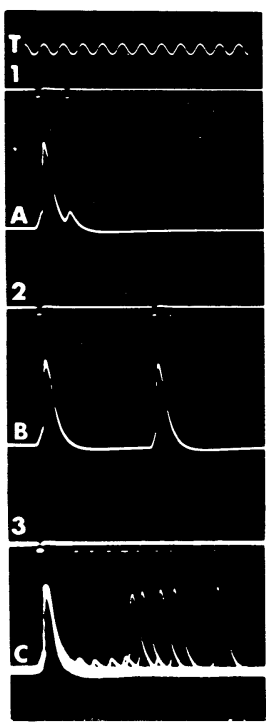

ENM
図 6 相対不応期中にわずかと閣上の刺電流（一 定)に上って現れたAP
$\mathrm{N}$ の場合

第 1 束激電流(a) $210 \mathrm{mV}, 0.3 \mathrm{msec}$ 第 2 束檄電流(b) $210 \mathrm{mV}, 0.3 \mathrm{msec}$ a とbの間程 $1.1 .5 \mathrm{msec}$

$$
\text { 2. } 6.2 "
$$

ENMの場合 $300 \mathrm{mV}, 0.2 \mathrm{msec}$ $300 \mathrm{mV}, \quad 0.2 \mathrm{msec}$ $2 \mathrm{msec}$ $5.5 \prime$
Cは数回の記錄の superimpose

現れた A Pについては, 大んさおよび期間の正確な判 定は困難であった。

2. 相対不応期中に適用された刺激電流（わずかに 閾上）に対するA Pの大いさ

相対不応期中の種々の時点において，それぞれの時 点における闌よりわずかに強ら刺激電流（期間一定） を適用した場合に，それに対するA Pの高さおよび期 間は，大体前項 1. 場合と同様であった. 第 1 の P に近い時点で現れる第 2 の A P ほど高さおよび期間は 小で, 現れる時点があとになるに従って高さ期間とも 大となり, 数 $\mathrm{msec}$ 後に現れたものは正常の場合の A P と大体同様になった（図 6 ).

3. A P の経過中に過分極電流を適用した後に現れ るA Pの大んさ

A Pの下降枝の期間中（坐骨神経の A P の場合には 正確には定め難い）に短期間の過分極電流を適用し, その後その時点における刺激閾よりわずかに強い刺激
電流を加えて現れる A P の高さおよび期間は, 過分極 電流がある強さ以上であれば正常の場合と同様の大き さであった（図 7 ).

A Pのplateau中に過分極電流を適用した場合には， 適用電流が小であれば適用期間中 A P 亿切れてみが現 れ，その後再び A P は持続するが, 電流を適用しない 場合の経過より一層高くかつ持続時間は延長した. 適 用電流が強い場合には A P は打消され第 1 の P が終 った後において第 2 の刺激電流によって現れるA Pの 高さおよび期間の関係は，下降枝の期間中に過分極電 流を適用した場合と同様であった（図 8 ）.

4. A Pの経過中に脱分極電流を適用した後に現れ るA Pの大んさ

第 1 の P の下降枝に脱分極電流を適用した場合に,

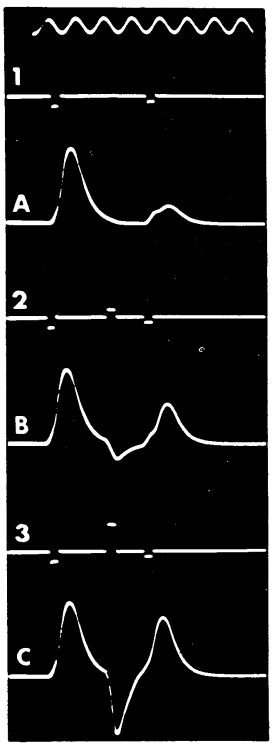

$\mathbf{N}$

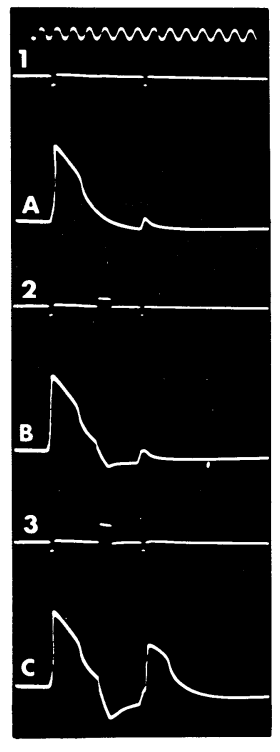

ENM
図 $7 \mathrm{AP}$ の下降枝の期間に過分極電流を適用しそ の後一定間程を経て適用した第 2 刺敫電流（一定）に 対して現れた AP

$$
\mathrm{N} \text { の場合 }
$$

ENMの場合

第 1 刺敫電流(a) $\quad 100 \mathrm{mV}, 0.3 \mathrm{msec} \quad 300 \mathrm{mV}, 0.2 \mathrm{msec}$ 過分極電流(b) 1

2. $70 \mathrm{mV}, 0.3 \mathrm{msec} 340 \mathrm{mV}, 1 \mathrm{msec}$

3. $400 "$ " " $690 "$ "

a とbつ間程 $\quad 1.8 \mathrm{msec} \quad 3 \mathrm{msec}$

第 2 刺淂電流 $(\mathrm{c}) \quad 55 \mathrm{mV}, 0.3 \mathrm{msec} \quad 300 \mathrm{mV}, 0.2 \mathrm{msec}$ bと c の間程 $\quad 1 \mathrm{msec} \quad 1.8 \mathrm{msec}$ 


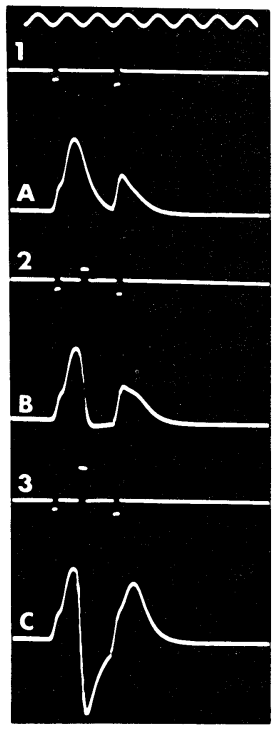

$\mathbf{N}$

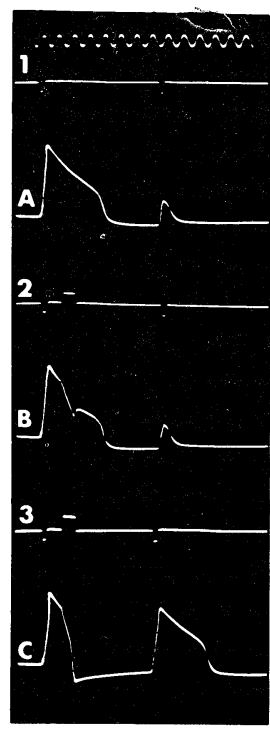

ENM
図8 APのplateauの期間に過分極電流を適用し その後一定間程を経て適用した第 2 刺敫電流（一定） に対して現れたAP

\section{Nの場合ＥNMの場合}

第 1 刺昽電流(a) $\quad 65 \mathrm{mV}, 0.2 \mathrm{msec} \quad 300 \mathrm{mV}, 0.2 \mathrm{msec}$ 過尔極電流(b) 1

2. $170 \mathrm{mV}, 0.2 \mathrm{msec} 520 \mathrm{mV}, 1 \mathrm{msec}$

3. $400 "$ " $690 "$ ",

$\begin{array}{cll}\mathrm{a} \text { と } \mathrm{b} \text { D間程 } & 0.7 \mathrm{msec} & 1 \mathrm{msec} \\ \text { 第2刺激電流(c) } & 180 \mathrm{mV}, 0.2 \mathrm{msec} & 300 \mathrm{mV}, 0.2 \mathrm{msec} \\ \mathrm{b} \text { と } \mathrm{c} \text { の間程 } & 1 \mathrm{msec} & 5 \mathrm{msec}\end{array}$

脱分極電流が終った後に現れる第 2 の P の高さおよ び期間は次の如くであった. 脱分極電流が相当強々場 合にはこの電流によってA Pが現れるので, 脱分極電 流によってA P が現れない強さにして，乙の電流を 適用した後に第 2 の刺激電流（第3の電流）を適用し て現れる A P の高さおよび期間第 1 の P の経過中 に脱分極電流を適用しない場合に同じ時点から起る

A P の高さおよび期間と比較すれば, 脱分極電流を適 用したあとのA P の高さおよび期間はより小であった (図 9 ).

第 1 の P D plateau の期間に脱分極電流を適用し た場合は, それが強い場合には適用した脱分極電流が 終ったあとで第 1 D P は速かに下降するが, 電流が 娽い場合には plateauに電流の期間に相当して凸所が
でき，電流が終った後，再び plateau が現れた（図10). レずれの場合にも脱分極電流が終った後で現れる A P の大んさは，脱分極電流が適用されなかった場合に， 第 1 の P D下降枝のあとの同様の時点から現れる A P と比較して，その高さおよび期間が幾分小さんか 大差ないものであった.

B. 実験A の場合のA Pとそれに対応する E X C

1. 実験 A の種々の場合につんて A P 経過とそれ に対応する舆奮性（EXC）の経過

Thyristor の gate と cathode の間の電位差の変動 の経過 (EXC) を記録し, この経過と共に相対不応 期およびその期間に現れたA P の高さ，期間等を観察 した結果は次の如くであった. EXCはAPのplateau の終りの時点から急速に下降して正常の值を越えて更

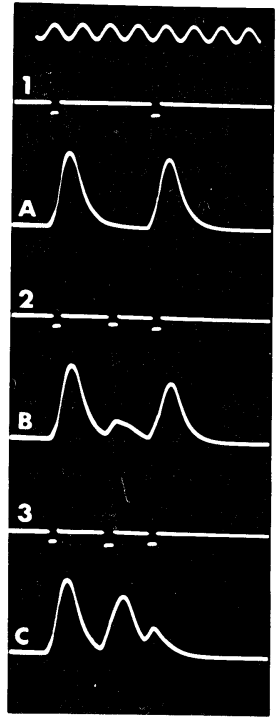

$\mathbf{N}$

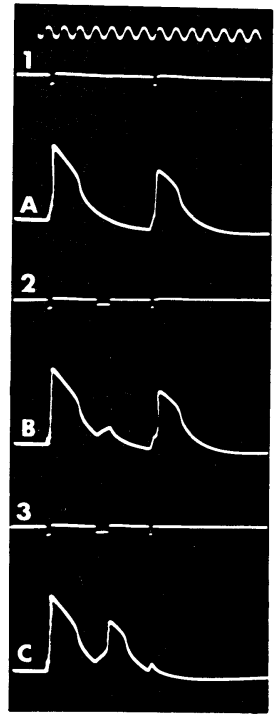

ENM
図 $9 \mathrm{AP}$ の下降枝の期間に脱分極電流を適用しそ の後一定間程を経て適用した第 2 刺激電流（一定）に 対して現れたAP

\section{Nの場合ＥNMの場合}

第 1 刺糡電流(a) $\quad 100 \mathrm{mV}, 0.3 \mathrm{msec} 300 \mathrm{mV}, 0.2 \mathrm{msec}$ 脱分極電流(b) 1

2. $110 \mathrm{mV}, 0.3 \mathrm{msec} 190 \mathrm{mV}, 1 \mathrm{msec}$

$\mathrm{a}$ と $\mathrm{b}$ の間程

3. $170 "$ " " $240 "$ " "

第 2 刺敫電流 $(\mathrm{c}) \quad 100 \mathrm{mV}, 0.3 \mathrm{msec} \quad 300 \mathrm{mV}, 0.2 \mathrm{msec}$ b.と c の間程 $\quad 1.3 \mathrm{msec} \quad 2.4 \mathrm{msec}$ 
に低下し，最低点にいたって上昇に向い，数 $\mathrm{msec} の$ 後正常の高さに戻った（図11），EXCが正常の值以 下（図 $11 の p, \dot{q}, r$ 亿おいて基線以下）の期間は正常 の場合より興奮が起り難い期間，すなわち相対不応期 である. A P の plateauの終点以後の下降枝の期間は、, 興奮期間（plateau）飞放電した $\mathrm{Cm}$ が再充電される 期間である．また，EXCと基線の間の距離は， $\mathrm{Cm}$

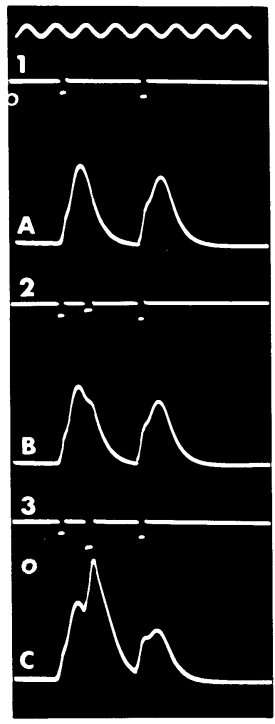

$\mathbf{N}$

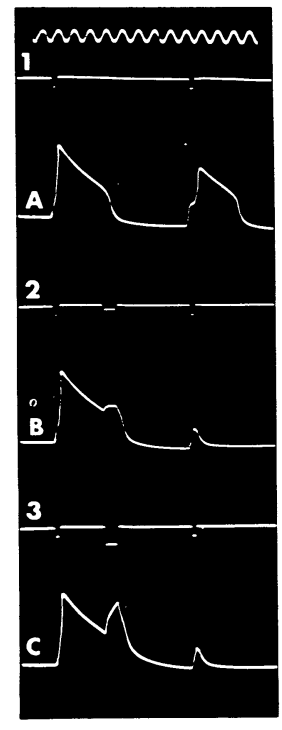

ENM
図 $10 \mathrm{AP} の$ plateauの期間飞脱分極電流を適用し その後一定間程を経て適用した第 2 刺影電流（一定） に対して現れたAP

$$
\mathrm{N} \text { の場今 ENMの場合 }
$$

第 1 刺徼電流(a) $\quad 75 \mathrm{mV}^{\prime}, 0.2 \mathrm{msec} \quad 320 \mathrm{mV}, 0.2 \mathrm{msec}$ 脱分極電流(b) 1 . -

2. $40 \mathrm{mV}, 0.2 \mathrm{msec} 160 \mathrm{mV}, 1 \mathrm{msec}$

3. $260 "$ " " $650 "$ " "

a とbの間程 $\quad 0.7 \mathrm{msec} \quad 2.8 \mathrm{msec}$

第 2 刺激電流( $\mathrm{c}) \quad 85 \mathrm{mV}, 0.2 \mathrm{msec} \quad 360 \mathrm{mV}, 0.2 \mathrm{msec}$

$\mathrm{b}$ と c の間程 $\quad 1.5 \mathrm{msec} \quad 4.6 \mathrm{msec}$

の電圧が正常の場合より低い程度を示するのである. 図11 亿ついてみるに, EXCが正常値（基線）に比較 してょり低い時点で起ったA P浭ど高さおよび期間が

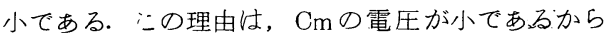
A Pが起ーたとを thyristor を流れる電流は $\mathrm{Cm}$ の電 圧がより高い場合に比較して小でそのため thy ristor の導通りこよって起る電压変動が小で, 膜電位（をたは
静止電位) の減少が少らので現れる A P の高さは小さ 々. また $\mathrm{Cm}$ の容量が一定なら， $\mathrm{Cm}$ の電圧が小なる

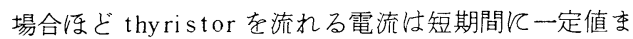
で減少するので, thyristorの保持電流忙短期間に終 り, 従って導通期間は短く，A P の期間は小となる.

2. A P の経過中に過分極電流を適用した場合の A P と対応する $\mathrm{EXO}$

実験 A 3 の場合に，A Pの経過とそれに対応する EXCの経過ならびにその後に現れるAPの高さおよ び期間の大をさにつんて観察した結果は次の如くである.

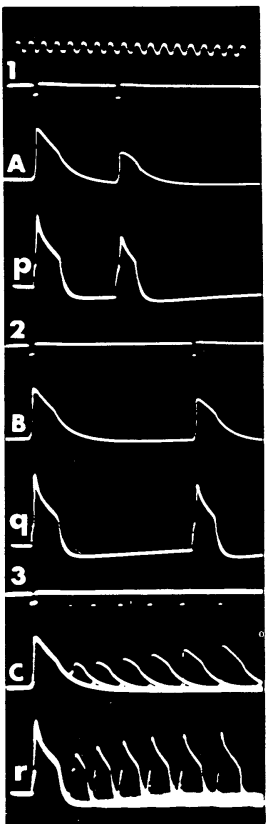

ENM

図 11 ENMの相対不応期中に現れたAP と興 窝性の経過（EXC）

$A, B, C$ :活動電位, $p, q, r$ :興鹪性の経過, $p, q, r$ において始めの直線部分は興鹪性正常の level, この線より上は興奮性が高く、下は興奮性が低 レことを示す。

第 1 刺敦電流(a) $480 \mathrm{mV}, 0.2 \mathrm{msec}$ 第 2 刺敫電流( b) $480 \mathrm{mV}, 0.2 \mathrm{msec}$ a とbの間程 $1.6 \mathrm{msec}$ 2. $12 "$

3. Cおよび $\mathrm{r}$ 数回の記録の superimpose $\mathrm{p}, \mathrm{q}, \mathrm{r}$ 等の小文字を付した $\mathrm{t}$ race はそれぞれ A B , C等行対する興奪性の経過 (EXC) を 表す（図12１5においてす同じ）。 
A P の下降枝の期間飞, 期間一定 $(0.5 \mathrm{msec})$ の 種々の強さの過分極電流を適用した場合の AP, EXC およびその後に現れる A P の高さおよび期間は図 12 に示した如くである．EXCが正常より低い間に弱い 過分極電流を適用すれば，その後に起る A P は, 高さ 期間ともに正常の場合より小である，過分極電流が大 なる場合には, 過分極電流が終って短期間の後, EXC は正常の場合より高くなるので, この時点において起 る A P は高さ期間ともに正常の場合のそれと同様か, 場合によっては幾分大であった（図12）。

過分極電流を A P の plateau の期間飞適用した場合 には, ${ }^{12)}$ 過分極電流の強さによって2つの場合が 現れた. すなわち過分極電流が弱らとをは, plateau

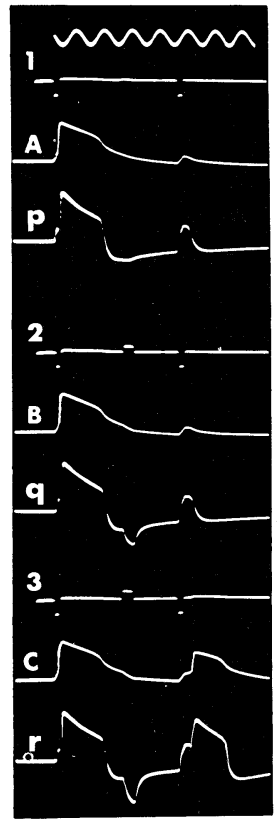

ENM

図 12 ENMのAPの下降枝の期間飞過分極電 流在適用しその後一定間程を経て適用した第 2 刺敫電流（一定）飞対する $\mathrm{AP}$ と $\mathrm{EXC}$ 第 1 刺敫電流(a) $320 \mathrm{mV}, 0.2 \mathrm{msec}$

2. $80 \mathrm{mV}, \quad 0.5 \mathrm{msec}$ 3. $160 "$ " "

$\begin{array}{ll}\mathrm{a} \text { と } \mathrm{b} \text { の間程 } & 2.2 \mathrm{~m} \mathrm{sec} \\ \text { 第 } 2 \text { 刺敫電流(c) } & 350 \mathrm{mV}, \quad 0.2 \mathrm{~m} \mathrm{sec} \\ \mathrm{b} \text { と c の間程 } & 1.6 \mathrm{~m} \mathrm{sec}\end{array}$

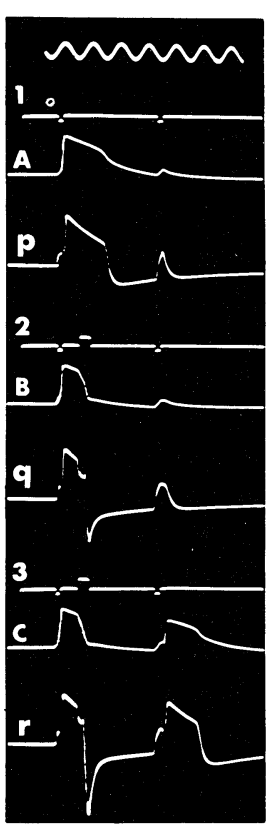

ENM

図 13 ENMのAPのplateauの期間に過分極 電流を適用しその後一定間程を経て適用した第 2 刺敫電流 (一定) に対する $\mathrm{AP}$ と EXC 第 1 刺敫電流(a) $320 \mathrm{mV}, 0.2 \mathrm{msec}$ 過分極電流(b)

2. $620 \mathrm{mV}, 0.5 \mathrm{msec}$

3. $640 ", "$

$\mathrm{a}$ とbの間程 $\quad 0.7 \mathrm{msec}$

第 2 刺激電流( $\mathrm{c}$ ) $340 \mathrm{mV}, 0.2 \mathrm{msec}$

b と c の間程 $\quad 2.3 \mathrm{msec}$

に切れてみが出来るが電流が終った後ふたたび plateauが続を，電流が強いとをは，plateauが現れな らで直ちに下降枝となった．前者の場合には，再び現 れたA Pの残りの部分が経過した後は, 通常のA Pが 終ったあとの $\mathrm{EXC}$ と同様で，乙の期間に現れる A P の高さ, 期間は小であった. 後者の場合には, EXCが 正常より高い点においてA P が起るので高さ，期間は 電流がない場合より大で，EXCが正常より低い点に おいて現れる A P は小であった，適用した過分極電流 の強さによって, 電流が終った後のEXCの高さが異 るので，その時点から現れるA Pの高さおよび期間は EXCの高さに依存して定まる. 
3. A P の経過中に脱分極電流を適用した場合 ${ }^{5)}$ A P と対応する EXC

A Pの下降枝は既に相詨不応期になっているので, 強い脱分極電流を適用すれば興奮が起るか, あるいは 加乞た電流の強さに従って興奮が起る方向に膜電位

（または静止電位）の変化が起る．いずれの場合にも $\mathrm{Cm}$ の充電が妨げられ，あるいは更に放電が起るので， $\mathrm{EXC}$ の経過は脱分極電流が適用されない場合より著 しく低下し，復旧が遅れる．乙の期間に現れるA Pの 大きさは，その時点における EXCの低下の度合いに 依存したものとなり, 脱分極電流が適用されない場合 に起るA P より高さ, 期間は小さいものとなった

(図 14 ).

A P の plateauの期間に脱分極電流を適用した場合

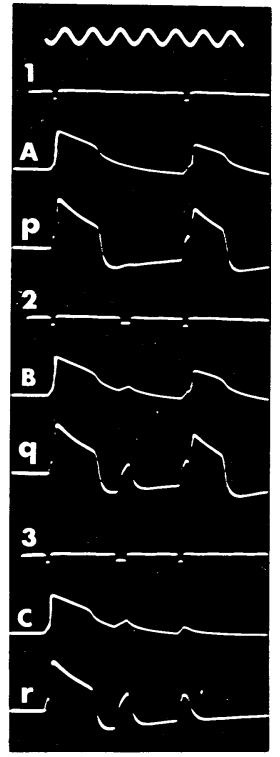

ENM

図 $14 \mathrm{ENM}$ の APの下降枝の期間に脱分極 電流を適用しその後一定間程を経て適用した第 2 刺嬏電流 (一定) に対して現れた AP と EXC 第 1 刺敫電流(a) $320 \mathrm{mV}, 0.2 \mathrm{msec}$

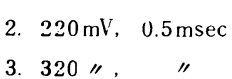

$\mathrm{a}$ と $\mathrm{b}$ の間程 $2.4 \mathrm{msec}$ 第 2 刺数電流(c) $350 \mathrm{mV}, 0.2 \mathrm{msec}$ $\mathrm{b}$ と $\mathrm{c}$ の間程 $\quad 1.8 \mathrm{msec}$

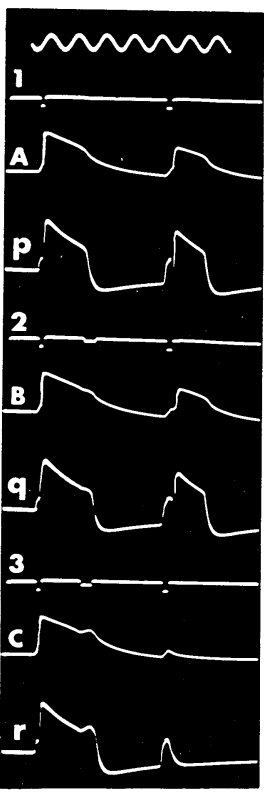

ENM

図 $15 \mathrm{ENM}$ のPのplateauの期間に脱分 極電流を適用してその後一定間程を経て適用し た第 2 刺敫電流（一定）に対して現れた APと

EXC

第 1 刺敫電流(a) $320 \mathrm{mV}, 0.2 \mathrm{msec}$

脱分極電流(b) 1 . -

2. $80 \mathrm{mV}, \quad 0.5 \mathrm{msec}$

3. $140 "$, "

a とbの間程 $\quad 1.3 \mathrm{msec}$

第 2 刺教電流 $(\mathrm{c}) \quad 340 \mathrm{mV}, 0.2 \mathrm{msec}$

$\mathrm{b}$ と $\mathrm{c}$ の間程 $\quad 2.5 \mathrm{msec}$

には、電流適用期間に相当して EXCに凸部が現れ， その高さは電流が強い場合ほど高い，凸部が低い場合 には，A P は再び plateauに戻るが，電流が適用され なかった場合より低い経過を辿る，凸部が高い場合に 沬，plateauに戻らないで直ちに下降枝となった（図 15 ). 凸部を経て再び plateau 亿戻る場合には，その 後の経過悦分極電流が適用されなかった場合の A P に対するEXCと同様になり，相対不応期およびその 間に現れる A P の大さ等も通常のA P の後と同様で あった．脱分極電流が終ったあと下降枝に移行する場 合，すなわちA Pが短縮された時は，EXCの低下， または上昇が妨げられる程度は少く，乙の期間に現れ る $\mathrm{A} \mathrm{P}$ は脱分極電流を適用しなかった場合に，乙れに 


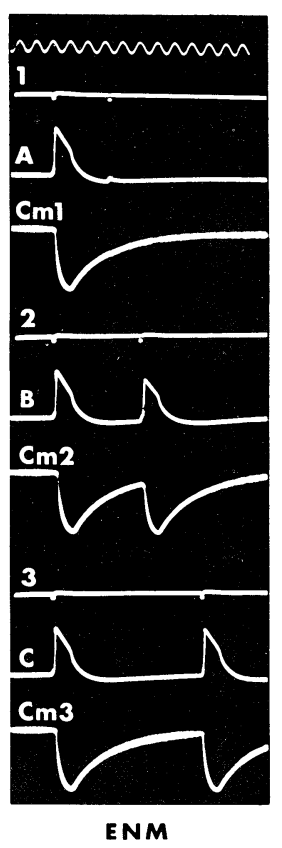

図 16 ENMの condense $\mathrm{r} \mathrm{Cm}(5 \mu \mathrm{F})$ の電 位の経過と現九た AP

$\mathrm{Cm}$ : condenser $\mathrm{Cm}$ の電位の経過, 始めの直 線部分は正常の電位, 下方への振れは電位の减 少を示す.

$\mathrm{Cm} 1, \mathrm{Cm} 2, \mathrm{Cm} 3$ はそれぞれA，B，C飞対す。 る $\mathrm{Cm}$ の電位の経過（下方への振れは電位の减 少)

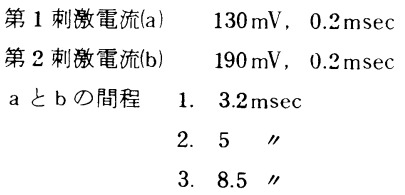

対応する時点から起る A P より高さおよび期間の減少 があらわれ，少くとも増大したものとはならなかった。

C. ENMの $\mathrm{Cm}$ の電压と AP の高さおよび期間の大々 さ

1. $\mathrm{Cm}$ の電圧変動の経過とA P の大んさ

図 $4(2)$ について興奮に伴 5 膜電位変動の経過と共に, $\mathrm{Cm}$ の電位変化を観察した結果は次の如くであった.

第 1 の P r対する刺激電流が適用された時点から $\mathrm{Cm}$ の電位は下降し, spikeの頂点から plateauの期 間は下降したまま持続し, plateauの終りから下降枝 《移る《及んで上㫒が起り，次第に初めの状態に戻る
(図 16). A P の下降枝におらて $\mathrm{Cm}$ の電位が初めの 值に戻らない期間（相対不応期）において現れる A P の高さおよび期間は，正常の場合より小である. Cm の電位が低ければ低い在ど, その時点から現れる A P の高さおよび期間は小であった．しかし， $\mathrm{Cm} の$ 電位 がある值以下の場合には興奮は起らない。乙の理由は、 thyristorの gate と cathode 間の電位が点孤電圧(EXCの臨界電位) 以上になっても, thyristor を流れ る電流が保持電流に達しないために刺激電流が作用し ている期間だけ電流が流れ, 刺激電流が止めば thy ristor 老流れる電流は中断するからである.

2. $\mathrm{Cm}$ の電位を変えた場合の A P の大んさ

図 4 (2)の回路におらて $\mathrm{Cm}$ を可変抵抗を以って短絡 し, 静止時における $\mathrm{Cm}$ の電位を種々の值にして, こ の状態から単独に現れた A Pの記録を観察すれば次の 如くであった。

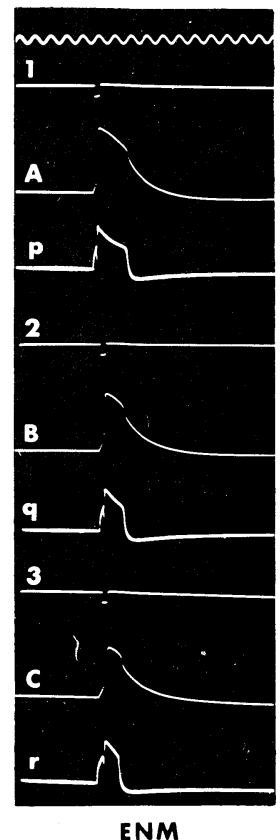

図 17 ENMの condenser $\mathrm{Cm}$ の電位を種々 の值にした場合に現れた AP と EXC $\begin{array}{ll}\mathrm{Cm} \text { の電位 } & \text { 1. } 1080 \mathrm{mV} \\ & \text { 2. } 1040 " \\ & \text { 3. } 1000 "\end{array}$ 刺敫電流 $320 \mathrm{mV}, 0.2 \mathrm{msec}$ 
$\mathrm{Cm}$ の短絡抵抗がめの場合，すなわち通常の場合の A P の高さおよび期間を規準にすれば，短絡抵抗が小 で $\mathrm{Cm}$ の電位が小である場合には，現れるA Pの高さ 怟く，期間汸小であった（図 17 ）。

3. A P の後に相対不応期（刺激閾が高い期間）が 現れない場合のA Pの大いさ

ENMの $\mathrm{Cm}, \mathrm{Cg}$ をたは Rcmの值を適当にすれば， 静止状態から起った第 1 の P のあと, 正常の場合の 刺激閾と同様の強さの電流でも A Pが現れるよ5にな る.しかし，乙の場合に現れる A P の高さおよび期間

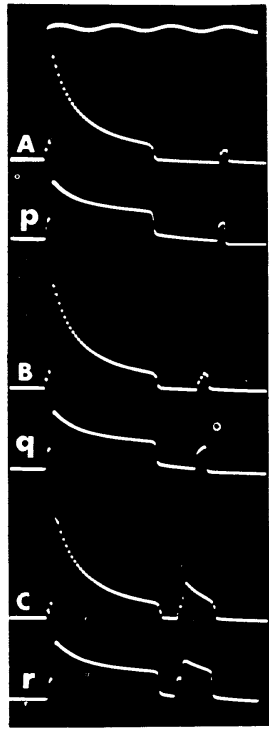

ENM

図 18 APのあと通常の場合飞相対不応期と して刺敫閥が高的期間が現れるがこの期間が全 く現れない場合

第 1 刺敫電流(a) $110 \mathrm{mV}, \quad 0.1 \mathrm{msec}$ 第 2 刺敫電流(b) $150 \mathrm{mV}, \quad 0.1 \mathrm{msec}$ a とbの間程 1. $2.4 \mathrm{msec}$

2. $2.8 \prime$

3. $3.2 "$

この記録の場合 ENMの素子の価, C : $5 \mu \mathrm{F}$, $\mathrm{Rcm}: 90 \Omega, \mathrm{Rm}: 2.5 \mathrm{~K} \Omega, \mathrm{Re}: 550 \Omega$, その他は, 他の場合と同し:

は第1のA P 亿比較して非常に小であった（図 18 ). すなわち，刺激閾については相対不応期が現れないが， A P の高さおよび期間は相対不応期に現れるものの如 く小であった。このよらな事から，相対不応期とは刺
激闇が通常の状態より高い期間であるとされていると とと, A P が小さんとととは分離可能のものである.

以上， $\mathrm{A} ， \mathrm{~B}$ および $\mathrm{C} の$ 夷験結果から，A P の高さ および期間が小であることの原因は， $\mathrm{Cm} の$ 電位が小 であることである. 相対不応期の期間における E XC の経過に関連して，A P の高さおよび期間が小である ことに対する原因が発現する，乙の上5に，刺激閾が 高らととに対する原因と A P の高さおよび期間が小で あることの原因の両者が発現するのが一般であるが， 両者に対する原因は同じではなく両者は分離するとと が出来る.

$\mathrm{N}$ 考按

A 実験成績 A ておらて, 相対不応期中に現れるA P の高さおよび期間が, 静止状態から単独に現れる A P のそれより小さんこと，A P の経過中に過分極電流京 たは脱分極電流を適用することによって, そのあとに 起るA P の高さおよび期間が受ける影響は坐骨神経と ENMKおいて全く同様であるてとを示した. このて とと, 神経線維に関する殆んど全ての既知の現象は ENM おんて神経線維におけると同様の状況で現れ るといら著者等の既報の事実を前提として, 次の如を 結論を導くことが出来る.

すなわち実験成績 B 亿述べた如く，相対不応期中に 現れる A P の高さおよび期間が小であるてとの原因を ENMを用いて明らかにし，乙のてとを直ちに神経線 維における該当する現象に適用して間違いないである 5と云ら結論である.

神経線維について, 相対不応期中のA P の高さおよ び期間が小さい原因を考えると，次の如くなるであろ 5.

E NMの Cmは, 神経線維の場合には, 荷電された 興奮性膜の電気容量 ( $\mathrm{Cm}$ の容量) に相当し，その荷 電 $(\mathrm{Cm}$ の荷電) のために神経線維の興奮性膜の透過 性が増大（thyristorの導通）した場合に電流が流れ る. 興奮性膜の電気容量の荷電が小で, 透過性が増大 した際に流れる電流が小さらとさは，A P の高さは小 となり，乙の電流が流れる期間が小であるので， A P の期間が小さん，相対不応期中に現れるA Pの小さい ことをENMを用いて探求した結果を神経線維に適用 すれば以上の如くなる.

この場合に，神経線維内に ENMの如を構造の回路 の存在を云々することは当を得たものではなく，神経 
線維の構成が全体としてENMの如をものであり, 個 々の構成要素が神経線維のどの部分に当るかは, 現在 はなお不明の問題である.しかし，研究の進展と共に， これらのととは次第に明らかにされ得る可能性は存在 する.

B 生理学の成書, (2) 3) 4) 相対不応期等飞関する研究報

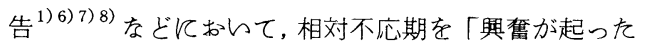
後において, 正常の場合上り刺激閾が大で, 現れる興 舊が小さい期間」と述べているものが多数あるが，乙 れ的て次のととを述べる要がある.刺激閾が通常 の場合より高いととは，興鹪性 EXCが低下している ことによるが，現れる A P が通常の場合のそれより小 さいととはENMでは $\mathrm{Cm}$ の電圧が低らととに基くも のであって,・刺激闌が高いととと，A P が小さんとと の原因は同一ではない。

しかし，通常の場合には，興奮が起ったあとに相対 不応期が現れる条件に関連して,APが小さい条件も同 時に発生する。すなわち両現象に対する条件は同一で はないが，乙れらは同一の原因から派生する2つの異 なる原因《基的て現れる. 従って, 両現象㤌不可分の 如く見なされるが，分離も可能である.

\section{$\mathrm{V}$ 総括}

実験材料として，カエルの坐骨神経および著者等が 神経線維の実験的等価回路として構成した䉓気的神経 模型（E N M）を用い，相対不応期中に現れる活動電 位（A P ）の高さおよび期間が，通常の場合の A P の それらより小であるてとの原因を明らかにしょらと企 てて実験を行い，次の結果を得灰。

1. 坐骨神経およびENMVおいて, 相対不応期中に 加えられたわずかと閾上の第 2 の刺敫電流に対して 現れるA Pの大いさは, 第 2 刺敫電流が第 1 の $\mathrm{P}$ 亿接近して適用された場合偟ど，高さおよび期間は 小であった.この現象は、神経およびENM両者に おいて全く同様に現れた。
2. A P の経過中に，過分極電流および脱分極電流を 適用し，その後に現れる相対不応期の期間中に生ず るA Pの大いさの変化は，神経およびENMにおい て同様であった。

3. 1 および 2 の場合において, ENMを用いてA P と共て興奮性の経過（EX C）を記録し，あるいは E N M の A P と共に Cmの電圧の経過等を観察し， 相対不応期中においては $\mathrm{Cm}$ の電位が正常上り低い ことが，A P の高さおよび期間が小であるととの原 因であることが知られた。

4. 前項 1 および 2 の結果, ならびに神経に現れる既 知の電気現象壮殆んど同様の状態で E N M 亿も現れ ることについての著者等が既報した事実を基礎にし、 て, ENMは神経線維の実験的等価回路であって, 神経の不応期中に現れる A P の高さおよび期間が小 なることとついてENMにおいて明らかにされた機 序は，乙れを神経の場合飞適用するととが出来ると の結論に達した。

5. 上記 4 飞従って, 不応期中の A P の高さお上び期 間の小なる原因は，E N Mを構成する $\mathrm{Cm}$ の電位が 小であることであり， thyristorが導通した時に流 れる電流が小で，このために現れる電圧変動が小で あり，持続期間が小さんことが原因である.乙れを 神経線維の場合につけて考えれば, A P 発現に際し て透過性が増大し，荷電した電気容量のために流れ る電流が小で，その部で起る電圧変動が小さいため A P の高さは小, 電流の持続時間が短いため A P の 期間は小となる.

6. 相対不応期は刺激闌が上昇した期間であるとすれ ば，その間に現れる A P の高さおよび期間が小なる ことは，相対不応期とは別の原因に基らて現れる現 象で，不可分のるのではない， 


\section{文献}

1) Araki, T. and Otani, T. Accommodation and local response in motoneurons of toad's spinal cord. Jap. J. Physiol. 9: 69, 1959.

2) Eccles, J. C. The neurophysiological basis of mind. Oxford, at the clarendon press, 1953.

3) Hodgkin, A. L. The ionic basis of electrical activity in nerve and muscle. Biol. Rev. 26:339, 1951.

4) Grundfest, H. Bioelectric potentials. Ann. Rev. Physiol. 2: 213, 1940.

5）入内島十郎 人体の生理学, 医学出版社 1970.

6）松本政雄 電気化学系による生理現象の再現と機 序の研究, 日本生理誌 $32 ： 581,1970$

7）松本政雄, 北村奉正, 半場道子 神経線維の等価 回路と電気的神経模型，日本生理誌 $35: 639$, 1973.

8）松本政雄, 北村奉正, 菊地幸江 活動電位を発現 する神経回路について, 日本生理誌 33：272, 1971.

9）松本政雄，北村奉正 不応期の研究，未発表

10）松本政雄，北村奉正，半場道子 電気的神経模型 による神経線維の不応期ならびに適応の成因の研 究, 未発表

11）本川弘一生理学, 南山堂 1962 ,

12) Ooyama, H. and Wright, E. B. Effect of anodal and cathodal pulses applied during action potential at a single Ranvier node. Am. J. Physiol.
197: 1247, 1959 .

13) Sato, M. Repetitive responses of the nerve fiber as determined by recovery process and accommodation. Jap. J. Physiol. 2 : 277, 1952.

14) Spyropoulus, C. S. Changes in the electric re sponse of single nerve fibers following repetitive stimulation. J. Gen. Physiol. 40: 19, 1950.

15）鈴木忠男 心筋の不応期に関する研究，電気生理 学研究 $16: 89,1957$.

16）武重祐彦骨格筋の恢復曲線について，電気生理 学研究 $10 ： 79,1956$

17) Tasaki, T. The excitatory and recovery processes in the nerve fibre as modified by temperature changes. Biochim. Biophys. Acta. 3: 498, 1949.

18) Tasaki, I. Initiation and abolition of the action potential of the single node of Ranvier. J. Gen. Physiol. 39 : 377, 1956.

19) Tasaki, I. and Hagiwara, S. Demonstration of two stable potential states in the squid giant axon under tetraethylammonium chloride. J. Gen. Physiol. 40 : 859, 1957.

20) Vallbo, A. B. Accommodation related to inactivation of the sodium permeability in single myelinated nerve fibers from xenopus laevis. Acta physiol. scand. $61: 429,1964$

21）山木邦清 無髄神経の回復過程に関する研究, 電気 生理学研究 9：79,1956. 
神経の相対不応期に現れる活動電位の大いさについて

\title{
ORIGIN OF SMALL AND SHORT ACTION POTENTIAL ELICITED DURING THE RELATIVE REFRACTORY PERIOD OF NERVE
}

\author{
MICHIKO HANBA
}

Department of Physiology, School of Medicine,

Gunma University, Maebashi, Japan

(Director: Prof. Masao Matumoto)

It had been well known that the smaller height and shorter duration of the spike occurred during the relative refractory period than those in the normal state of the nerve. But the reason is still not elucidated at all. In this paper the results of investigation of these phenomena were reported. Materials used in the experiments were the sciatic nerve of the bullfrog and the electric nerve model (ENM) composed of elect ric elements and devised by Matumoto et al. This model is an equivalent circuit of the nerve fiber representing almost all phenomena already known on the nerve fiber in similar state as in it.

Therefore, the author assumed that the mechanism of these phenomena could be substituded with that elucidated on the artificially composed ENM for the same phenomenon. The following were the obtained results.

Reduced excitability due to the decreased charge of the capacity of the excitable membrane was the origin of the higher threshold in the relative refractory period, while the smaller height and shorter duration of the spike resulted from the weaker intensity of the discharge current of the capacity of the excitable membrane. Both phenomena appeared by the same origin in general case, but in details the mechanism was different in these two, and they could be separated in the special case. 